\title{
How planktonic microcrustaceans respond to environment and affect ecosystem: a functional trait perspective
}

\author{
Elder de Oliveira Sodré (iD - Reinaldo Luiz Bozelli
}

Received: 26 March 2019/Accepted: 9 July 2019/Published online: 17 July 2019

(C) The Author(s) 2019

\begin{abstract}
Functional traits are ecologically relevant characteristics of species. They are relevant to community structuring in face of environmental drivers (response traits) and to ecosystem processes (effect traits). For planktonic microcrustaceans, the link between functional traits and their responses or effects is not always clear. Our objective was to review the literature on linking functional traits to environmental drivers and ecosystem processes for planktonic cladocerans and copepods. Response traits are discussed in four categories: morphological, life history, behavioral, or physiological. Temperature, predation, resources, and stressors are important drivers of morphological and life-history traits. Body size, a morphological trait, is probably the most important trait, because it responds to several environmental characteristics and is correlated with physiological traits and to zooplankton impact on ecosystems functions. In an ecosystem perspective, zooplankton is an important energy link between primary producers and secondary consumers. In trophic webs, it may control phytoplankton biomass and productivity, with consequences for whole lakes. Its influence on carbon, nitrogen, and phosphorus cycles is expected to increase with body size. Other traits may be important, but there is a lack of information. We point out the need of more functional trait research, especially with freshwater copepods and neglected tropical species. For a better understanding of natural systems, an integrative approach of multiple traits with multiple environmental drivers and ecosystem functions is necessary.
\end{abstract}

Keywords Zooplankton · Functional diversity $\cdot$ Cladoceran $\cdot$ Copepod $\cdot$ Environmental drivers $\cdot$ Ecosystem function

\section{Introduction}

Biodiversity is the variety of life on Earth, including several levels of biological organization: from genetic variants of the same species to arrays of species, genera, families, and even higher taxonomic levels (Noss 1990). The world is facing a huge biodiversity loss (Cardinale et al. 2012) due to factors such as habitat loss, climate change, biological invasions, among others (Thomas et al. 2004; Galiana et al. 2014; Segan et al. 2016). In face of these threats, scientists have been developing new methods and approaches to measure biodiversity and its ecological and practical relevance.

E. d. O. Sodré $(\bowtie) \cdot$ R. L. Bozelli

Departamento de Ecologia, Universidade Federal do Rio de Janeiro, CCS, IB, Caixa Postal 68020, Rio de Janeiro,

RJ CEP 21941-970, Brazil

e-mail: elder.limnologia@gmail.com 
There are several ways of measuring biodiversity, e.g., species richness, diversity indices, and functional diversity (Magurran 2004). Among them, we highlight functional diversity. Functional diversity explicitly refers to characteristics of organisms; thus, it is considered to be a good predictor of community assembly (McGill et al. 2006), ecosystem functions (Tilman 1997; Díaz and Cabido 2001), and even biogeography (Violle et al. 2014).

A definition of functional diversity is the value, range, and relative abundance of species' functional traits (Chapin et al. 2000; Hooper et al. 2005). A fundamental concept, thus, is functional trait: characteristic measured at individual level that impacts fitness indirectly via its consequences on growth, reproduction and survival. An important distinction in this regard is response versus effect traits: response traits vary in response to changes in environmental conditions and effect traits reflect the effects of species on ecosystem or community properties (Violle et al. 2007; Hébert et al. 2017).

Functional diversity is usually measured as functional groups or indices. The former are groups are of ecologically similar species and can be defined a priori or a posteriori (Pla et al. 2012). The latter are a value calculated based on the functional traits present in the community. Several functional indices have been proposed: dendrogram-based functional diversity, functional richness, functional evenness, functional divergence, functional dispersion, among others (Petchey and Gaston 2002; Laliberté and Legendre 2010; Mason et al. 2005). All approaches, including different groups and indices, depend on the selection of traits and other methodological choices in calculations (Lepš et al. 2006; Poos et al. 2009). For a functional diversity measure to be ecologically relevant, the traits used must reflect the ecological processes of interest (Rosado et al. 2013), whether community assembly (Pavoine and Bonsall 2011) or ecosystem functions (Cadotte et al. 2011).

The study of functional diversity started with land plant communities (Tilman 1997). Today, plants are the most studied group in a functional perspective (Calaça and Grelle 2016). In aquatic communities, there are several classifications of phytoplankton functional groups (Reynolds et al. 2002; Kruk et al. 2010), plus some modifications of the originals (Padisák et al. 2009). For zooplankton, Barnett et al. (2007) provided the first compilation of functional traits, focused on North American freshwater microcrustaceans. Since then, the study of functional diversity in zooplanktonic communities has been increasing. However, the links between functional traits and environmental drivers or ecosystem functions is not always clear. Some traits have been linked to the fitness of organisms or to ecosystem properties (Litchman et al. 2013; Hébert et al. 2016b, 2017), but the understanding of traits at community level is largely incomplete.

Our objective is to review the functional traits of planktonic microcrustaceans (cladocerans and copepods). We discuss the theme in both freshwater and marine ecosystems, as there are similarities in functional traits of copepods independently of their environment. Using information published on the literature, we give an overview of links between environmental drivers and ecosystem processes to response and effect functional traits.

\section{Response of zooplankton functional traits to the environment}

In this section, we review the influence of environmental drivers on response traits, at population and community level. We categorize functional traits in four different types: morphological, life history, behavioral, and physiological (Litchman et al. 2013).

Morphological traits

Morphological traits are those related to the size and shape of organisms. Body size is the main morphological trait. Body size is an integrative trait, i.e., it is influenced by several factors and is linked to several ecosystem processes performed by zooplankton. It is intrinsically linked to growth and reproduction of organisms (Litchman et al. 2013). Respiration and excretion increase with body size; thus, zooplankton role on carbon and nutrient cycles increases as well (Hébert et al. 2016b). Several factors may determine the body size of cladocerans and copepods. These factors are related mainly to environment and to interactions with other organisms (Hart and Bychek 2011). Other morphological traits, such as the presence of morphological defenses against predators, will be discussed together with body size. 
The two most common measures of body size are length and weight. Even though they use different units, individual length and weight are highly correlated and respond to the same environmental factors. With body length information, it is possible to estimate body weight using allometric equations reported in the literature (Dumont et al. 1975; Bottrell et al. 1976). Due to these similarities, body length and weight will be treated together as body size.

\section{Temperature}

Temperature is probably the main factor that affects body size of organisms in general, including microcrustaceans (Kappes and Sinsch 2002; Engert et al. 2013). Several laboratory experiments have demonstrated that both cladocerans and copepods achieve smaller body sizes and individual biomass at higher temperatures (Moore and Folt 1993). The magnitude of such responses to temperature vary among species, and even on genetic lineages within the same species (Bruijing et al. 2018). Other factors interact with temperature to determine body size (Sebastian et al. 2012), such as presence of predators (Kappes and Sinsch 2002), chemical stress (Engert et al. 2013), and food concentration (Ban 1994), but usually with weaker effects.

The explanation is a well-known rule in ecology, the temperature-size rule (Atkinson 1994). It states that, in colder conditions, ectotherms grow slower, but reach larger body size; in warmer conditions, ectotherms grow faster, but achieve smaller size (Angilletta et al. 2004; Kozlowski et al. 2004). This rule is widespread in both terrestrial and aquatic animals (Horne et al. 2017).

The temperature-size rule has some important implications. The first is, in multivoltine species, such as microcrustaceans, there is a seasonal variation in body size that matches temperature seasonality. In other words, individuals are smaller in warmer months (Horne et al. 2017). The second important implication is that there is a latitudinal gradient of body size, with smaller organisms close to equator and gradually larger organisms with increasing latitudes. This has been observed for freshwater cladocerans and cyclopoids (Gillooly and Dodson 2000; Havens et al. 2015) and partially for marine copepods (Brun et al. 2016). The third important implication of temperature-size rule is that temperature increases due to global climatic change will likely affect the size of organisms (Daufresne et al. 2009; Garzke et al. 2015; Rice et al. 2015), with consequences for the role played by zooplankton on trophic webs and ecosystem functions.

In a community perspective, temperature alters body size not only by modifying the length of each species, but likely also by altering the outcome of interspecific competition. In cold waters, larger species are competitively superior, whereas in warmer water, biomass of large species decreases and small species have competitive superiority (Feniova et al. 2011). Therefore, when water temperature increases, small species are favored over larger ones and community composition is altered. For example, increases in mean water temperature in an estuary in the Atlantic coast of USA caused changes in copepod community structure; comparing data from the 1950 s to the 2012 s, mean body size of common species Acartia tonsa and Acartia hudsonica decreased, two species of large copepods disappeared, and the small copepod Oithona sp. increased its proportion in community (Rice et al. 2015).

\section{Predation pressure}

Predation is also a primary influencer of zooplankton body size, as has been extensively reviewed in the literature (Zaret 1980; Greene 1983). In general, there are two types of predators that feed on zooplankton: visual and tactile. Visual predators are planktivorous fish that use their vision to localize prey and, therefore, select preferentially large, conspicuous prey. Filter-feeder fish are not visual, but prey size selection may occur depending on the mesh of the gills (Lazzaro 1987). Tactile predators are invertebrates, such as cyclopoids and Chaoborus, that detect prey by hydrodynamic signals related to movement, and select organisms small enough to be handled and ingested (Hart and Bychek 2011).

The idea that fish prey selectively on larger zooplankton is relatively old in ecology. Several authors have demonstrated a decrease in size of Daphnia in response to fish (Brooks and Dodson 1965; Green 1967; Zaret and Kerfoot 1975; Černý and Bytel 1991). Beyond body size, fish predation may have an impact on reproduction and life-history traits (Jeppesen et al. 2002). Fish may selectively prey on egg-carrying females, which are more conspicuous and more nutritive, impacting reproduction (Gliwicz et al. 2010); a possible response of Daphnia, in this case, is to reduce clutch size and size at first reproduction (Gliwicz and Boavida 1996). By 
decreasing population size and selectively removing large zooplankton, presence of fish has a cascading trophic effect, leading to changes in phytoplankton community (Christofersen et al. 1993; Pinto-Coelho et al. 2008). Other effects of fish predation include morphological defenses (Tollrian 1995) and production of resting eggs (Slusarczyk 2001).

Chaoborus larvae and cyclopoids are common predators in freshwaters around the world. Invertebrate predation may cause a decline in populations of cladocerans (O'Brien 2001). Smaller cladocerans, including younger individuals, are more vulnerable to losses by this kind of predation (Gliwicz and Umana 1994). In a study with tropical species, three species of cladocerans achieved higher body size at birth and in adults in the presence of Mesocyclops, a predatory copepod (Hwang et al. 2009). In another experiment, a predatory freshwater medusae did not affect Bosmina body size (Jankowski 2004). It seems that the effects of invertebrate predation may be different in tropical areas and for non-arthropod predators, but more studies are necessary to confirm that.

Effects of invertebrate predation include an increase in body size and formation of induced morphological defenses (Sell 2000; Jankowski 2004; Labaj et al. 2014). In Daphnia, morphological defenses include the formation of neckteeth and increases in helmet and caudal spines length (Sell 2000). In Bosmina, antenulles are longer in the presence of predators (Hellsten and Stenson 1995). The ability to change morphology also depends on environmental factors (Kappes and Sinsch 2002). However, not all species of cladocerans are able to change their morphology in response to predation. The ability to produce inducible morphological defenses is an important functional trait in lakes with predators.

\section{Resources}

Quantity and quality of resources may affect microcrustacean body size. The influence of resource quantity on body size depends on food threshold levels and incipient limiting concentrations (Hart and Bychek 2011). Food threshold levels are the minimum supply level above which growth is possible for individuals or populations. Incipient limiting concentrations are the food levels at which feeding rates are saturated; thus, above this level, food concentration does not influence body size anymore and organisms invest in reproduction instead (Polishchuk and Vijverberg 2005). Between these two levels, body size tends to increase with resource quantity. This is true, for example, for cladocerans (Gama-Flores et al. 2011). For copepods, there is evidence that body size increases with food availability as well (Klein Breteler and Gonzalez 1982). However, other research shows that adult copepod body size responds very little to resources and other environmental factors, because their development is more intrinsically regulated-e.g., genetically (White and Mclaren 2000)—rather than environmentally (Twombly and Tisch 2000).

Several studies have addressed the influence of resource quality on microcrustacean body size, and the general trend seems to be an increase in body size in higher resource quality (Klein Breteler and Gonzalez 1982; Nandini et al. 2013). Cladocerans achieve larger body size when fed with nutritious phytoplankton species, in comparison with less nutritious or edible phytoplankton (Repka 1997; Choi et al. 2014). However, this relationship is complex, because it depends on how you define resource quality (e.g., phytoplankton taxonomy, stoichiometry, and fatty acid content) (Hart and Bychek 2011). Phytoplankton shape also plays a role: filamentous algae may interfere with the feeding apparatus of larger cladocerans, favoring smaller ones (DeMott et al. 2001; Ghadouani et al. 2006).

Resource quantity and quality interact. Food of higher quality, defined as phosphorus content, decreases food threshold levels for Daphnia (Bukovinszky et al. 2012). The influence of resource quality is higher for cladocerans, because copepods have a selective feeding that allows them to avoid unwanted prey and choose more nutritional food items (Rao and Kumar 2002; Yang et al. 2010). However, the diet and feeding selectivity in copepods may depend on factors such as temperature (Gusha et al. 2019), phytoplankton taxonomy, and morphology (Isari et al. 2013).

\section{Chemical stressors}

Stressors are another important factor influencing body size of organisms and communities. Chemical stressors, such as pesticides, heavy metals, and acidification, decrease body size and fitness of organisms (Havens and Hanazato 1993; Pieters and Liess 2006; Rodgher et al. 2009). However, the magnitude of 
response may be species or lineage-specific (Sarma et al. 2007; Cruz-cisneros et al. 2008). Paradoxically, smaller species are more sensitive to heavy metal toxicity (Vesela and Vijverberg 2007), so there is likely a positive feedback: chemical stressors decrease body size, but smaller organisms are more sensitive to chemical stressors (Hart and Bychek 2011). This has consequences on the structure of communities. In an Italian lake, chronic chemical pollution led to decreases in body size of organisms, and shifts in community structure (Cattaneo et al. 1998).

Other kinds of stress lead to different effects. Mild stress by dissolved organic carbon (as humic substances) increases resistance to salt stress and has beneficious effects on body growth and life-history traits (Engert et al. 2013; Suhett et al. 2011). Pharmaceuticals are an increasing stress in freshwaters, but their effects on zooplankton are still largely unknown (Sarma et al. 2017).

\section{Other factors and interactions}

In nature, different factors with contrasting effects occur at the same time. For instance, in most lakes, zooplankton is subjected to both vertebrate and invertebrate predation, with contrasting effects on body size. Temperature and availability of resources often interact (Viitasalo et al. 1995; Primicerio 2003; Bozkurt and Can 2014). At the same time, in polluted lakes, chemicals may prevent organisms from developing morphological defenses and responding to predation (Sakamoto et al. 2009). Since multiple factors occur at the same time, it is hard to disentangle the effects of different variables. On the other hand, because body size responds to several different environmental characteristics, it may be used as an indicator trait, helping us understand environmental changes.

Ephipia of cladocerans in the sediment may be used to infer about the past environmental conditions, such as predation (Jeppesen et al. 2002; Korosi et al. 2013). In a Finnish lake, cladoceran assemblage composition and body size trends were used in a paleolimnological study to reconstruct the past climate variation in the Holocene (Nevalainen et al. 2015). In Canadian lakes, Daphnia body size decreased, since pre-industrial times, as a consequence of global warming, but acidification caused by industrial pollution also played a role (Korosi et al. 2010). With the decrease in acidification and eutrophication, as well as other environmental changes in those lakes, cladoceran size was reported to increase again in the past decades (Yan et al. 2008).

Physical characteristics of environment affect body size of communities as well. Ocean currents, upwelling and even salinity shape body size distribution in marine plankton communities (San Martin et al. 2006; Dvoretskii and Dvoretskii 2009). Different compartments of the ocean, such as coastal areas and open ocean, have different physical characteristics that influence body size (Tsuda et al. 2001). In aquatic continental ecosystems, despite the much smaller spatial scale, physical environment plays a role too. Land use in the catchment, hydrology, thermocline depth, among others, influences body size directly or indirectly (Beaver et al. 2014; Gauthier et al. 2014). Macrophyte banks provide a refugee against predation and thus may increase body size as a consequence (Basińska et al. 2014).

\section{Life-history traits}

Life-history traits include functional traits related to growth and reproduction of organisms, with consequences for population dynamics. Life-history traits include individual growth rates, neonate size, clutch size or egg production, age at first reproduction, among others (Stearns 1976; Litchman et al. 2013). They are usually measured in laboratory conditions, because following a cohort from birth to death, usually for more than one generation, is required.

Measuring some life-history traits is especially hard on the field. When information on life-history traits is not available, body size is a good proxy for them (Hébert et al. 2017). Larger sized organisms tend to have high growth, reproduction and survival. In cladocerans, species of medium-sized Machrothrix (not truly planktonic) have shorter lifespans and reproduce less than Daphnia and Simocephalus, which are larger (Huang et al. 2011).

To understand functional life-history traits, one must look at energy allocation and trade-offs. Organisms feed, and the energy acquired by feeding is allocated into growth, reproduction and survival (i.e., fitness components). However, as the energy is often constrained by availability of resources, organisms cannot maximize simultaneously all components of fitness. Thus, organisms make metabolic decisions (Acerenza 
2016), or trade-offs, to invest more in survival, growth, or reproduction and its corresponding life-history traits, depending on environmental conditions.

There are several examples of trade-offs in nature. In cladocerans, for instance, two species of co-existing Daphnia (D. longispina and D. cucullata) responded differently to predation: D. longispina invested in reproduction and large clutch sizes, and D. cucullata had low reproductive output but high body growth (Adamczuk 2010). In copepods, the marine species Calanus finmarchicus has larger body length at colder waters, but survival from copepodite to adult is lower in cold waters (Melle et al. 2014), which suggests a trade-off between growth and survival depending on water temperature.

Increasing amounts of food tend to increase life-history traits of organisms. When recovering from starvation, Daphnia promotes body mass growth at first. When resources increase, they are allocated to improve body condition and increase clutch size. Then, when food is no longer a limiting factor, most resources are used to increase clutch size (Polishchuk and Vijverberg 2005). In copepods, life-history traits tend to increase with resource availability as well (Hopcroft et al. 1998; Makino and Ban 2000). Food quality also plays a role. There is evidence that microcrustaceans have higher growth rates and produce more eggs when fed with food of higher quality (Repka 1997; Koski et al. 2010; Choi et al. 2014). Both quantity and quality of resources may constrain microcrustacean life-history traits (Ferrão-Filho et al. 2003).

Temperature is another major driver of life-history traits. Within the thermal tolerance range of organisms, rates of processes (e.g., growth rates and egg production rates) tend to increase with temperature. Consequently, other traits (e.g., body size and clutch size) decrease with temperature. The effects of temperature on biological processes are usually summarized in a thermal performance curve (Schulte et al. 2011), and when temperatures are too high, thermal stress prevents growth and reproduction of organisms. Understanding thermal tolerance curves and ecological interactions has important implications for predicting geographical distributions of species in face of global climate change (Pajk et al. 2018).

In the marine copepod Pseudocalanus newmani, cultivated at four different temperatures $\left(3{ }^{\circ} \mathrm{C}, 6{ }^{\circ} \mathrm{C}\right.$, $10{ }^{\circ} \mathrm{C}$, and $15^{\circ} \mathrm{C}$ ), body size decreased with increasing temperature, as expected. In addition, development time decreased, which means that body growth rate was higher at higher temperatures. Though clutch size decreased with increasing temperature, egg production rate increased and time interval between clutches decreased. However, when cultivated in the temperature of $20{ }^{\circ} \mathrm{C}$, embryonic and post-embryonic development, and egg production were suppressed due to thermal stress (Lee et al. 2003). Egg production rate of sac spawners (i.e., copepods that carry their eggs) in the oceans also has a positive relationship to temperature (Bunker and Hirst 2004).

Temperature and food quantity interact. For example, even at low temperatures, organisms will not grow under food limitation. Temperature and food availability have contrasting effects on clutch size: temperature tends to decrease clutch size and food availability tends to increase it. Nevertheless, at high temperature and high food availability, the effect of food increasing clutch size seems greater than the effect of temperature decreasing it (Giebelhausen and Lampert 2001). In natural environments, both factors interact with environmental heterogeneity, turning the relationships more complex (Koussoroplis and Wacker 2016). Zooplankton may migrate vertically and horizontally in search of the best temperature, resource, predator avoidance, and other conditions to maximize its fitness (Lampert 1989; Burks et al. 2002).

The presence of predators alters life-history traits, with consequences for population growth and structure. In the presence of planktivorous fish, a common response of large cladocerans is to reproduce earlier and increase clutch size, as an adaptation to counter the losses of individuals by predation ( $\mathrm{Gu}$ et al. 2017; Adamczuk 2012). A different response that occurs mainly in the presence of invertebrate predators is investing in inducible defenses such as elongated spines. This is a costly solution, which decreases egg production, and may deplete populations in the field (Manca et al. 2008; Adamczuk 2010). Copepods may also display lifehistory responses to predation. In a calanoid copepod, the presence of fish kairomones resulted in faster development time and earlier reproduction at a smaller body size, consequently producing less eggs per clutch (Gutiérrez et al. 2010).

The presence of chemical stressors in the water may have contrasting effects on life-history traits, depending on the nature and concentration of stressors. Mild stressors (like low concentration cupper and chemical plant compounds) may have beneficial effects, increasing body size and reproduction (GussoChoueri et al. 2012; Hofmann et al. 2012). Other stressors, such as exposure to UV, reduce growth and reproduction in cladocerans (Huebner et al. 2013). When fed on a diet rich in mycosporine-like amino acids, 
that act as natural sunscreens, copepods prevent deleterious effects of UV radiation (Hylander et al. 2014). In nature, organisms are exposed to multiple stressors. The response of organisms, in this case, are complex and may depend on past exposures to stressors (Jansen et al. 2011).

Other studies point out the effect of population density. Laboratory experiments demonstrated that, under crowded conditions, Daphnia reproduces earlier, at smaller size, and produces less eggs per clutch (Cleuvers et al. 1997; Ban et al. 2009). Increased population densities may also trigger sexual reproduction and the production of ephippia (Bunner and Halcrow 1977; Azuraidi et al. 2013). These life-history changes may reduce the chance of food limitation for neonates when population is growing rapidly (Guisande 1993).

\section{Behavioral traits}

Behavioral traits include information about how organisms feed, locomote, migrate, or escape predators. A basic quest for zooplanktonic organisms is to encounter particles that they need while avoiding predators in a dilute and viscous environment. Zooplanktonic organisms have evolved several ways to overcome the problem of finding food. Planktonic cladocerans are filter feeders: it means that they create a water current and pass it through a filter formed by their appendices. Functionally, the feeding of cladocerans is usually classified based on the morphology of their filter-forming structures. Chydoridae and Machrothricidae families, on the other hand, are scrapers, but they are not truly planktonic families. Such feeding characteristics are phylogenetically conservative in taxonomic families (Barnett et al. 2007). Copepods feed either by ambush feeding or by scanning-current feeding. In ambush feeding, the copepod remains motionless in water, and attacks prey that swim through their perception sphere. Scanning-current feeders generate a feeding current, then perceive and capture prey that approaches. Ambush feeding seems mandatory for cyclopoids. Most calanoids feed by generating feeding currents, or by both modes (Kiørboe 2010, 2011). These types of feeding are very efficient, and are pointed out as one of the factors that make copepods so successful, especially in the oceans (Kiørboe 2010).

The three feeding types capture organisms with different characteristics; ambush feeding is efficient towards more mobile prey species; scanning-current feeding is efficient towards non-motile, non-evasive prey; filter feeders capture a wide range of microorganisms with compatible sizes (Kiørboe 2011). Thus, cyclopoids are usually classified as omnivore and raptorial, and calanoids are herbivorous or omnivorous. Cladocerans, on the other hand, are usually classified as herbivorous (Barnett et al. 2007).

The way microcrustaceans acquire that their prey is relatively straightforward to classify functionally. However, their exact diet varies with food availability and concentration, among other factors. Filter feeders cladocerans consume non-motile, small phytoplankton cells, and select prey mainly by mesh size of their filtering apparatus (Barnett et al. 2007; Kiørboe 2011). Copepods are more selective in their diet, being able to choose prey based on their taxonomy (Isari et al. 2013). In a laboratory experiment, when a diverse array of prey were available, the copepod Mesocyclops thermocyclopoides consumed preferentially the rotifer Brachionus calyciflorus and the cladoceran Moina macrocopa (Rao and Kumar 2002). Morphology, swimming behavior, and speed are important in determining vulnerability of prey (Chang and Hanazato 2003). In the absence of their preferred prey, copepods will eat other food that is available in their environment (Kumar and Rao 1999; Makino and Ban 2000). In the oceans, calanoid copepods consume preferentially ciliates and dinoflagelates (Saiz and Calbet 2011), but some species may show preference to diatoms (Li et al. 2013). Such food preferences may determine the strength of trophic transfer from phytoplankton to fish.

Another important behavior trait is swimming and escape response to predators. Cladocerans swim by flipping their antennas, and therefore, they move in "jumps" across the water. In response to predators, cladoceran species have different responses. These responses may be a reduced swimming, where they stop moving, a rapid swimming, or pause and jumping (Chang and Hanazato 2003; Barnett et al. 2007). Copepod escape response to predators includes efficient detection of threats and fast swimming (Kiørboe 2010; Bradley et al. 2013; Yen et al. 2015). For example, less than $1 \%$ of encounters with a predatory medusae result in the copepod being ingested (Suchman 2000). However, body size and morphology in copepods are more intrinsically constrained than in cladocerans (Hart and Bychek 2011). Cladoceran escape response to predators includes not only differential swimming, but also development of spines and changes in body size across generations. 
In lakes, there are different compartments varying in depth, macrophyte cover, influence of surrounding terrestrial ecosystem, among others. Habitat is a trait that tells, where a species is more likely to be found in a freshwater ecosystem, being usually classified as either pelagic or littoral (Barnett et al. 2007). Pelagic species often live in central areas, without macrophyte cover. Littoral species live in shallow parts of the lake, with presence of aquatic macrophytes, and may not be fully planktonic. In response to planktivorous fish, cladocerans may respond by changing their vertical migration (Dini and Carpenter 1992), or seeking refugee in macrophyte banks (Burks et al. 2001). Habitat was an important to understand zooplankton community structure in an impacted floodplain lake, responding to depth and turbidity of sampling stations (Sodré et al. 2017).

Physiological traits

Based on the classification by Litchman et al. (2013), the way zooplankton feed, swim, and escape predators may be classified as behavioral traits. However, the rates at which these processes occur, among others, are physiological traits.

Feeding rates are the result of two components: the first is to encounter food and the second is to capture it (Kiørboe 2011). The feeding rates of organisms may be defined as either clearance rates or ingestion rates. The clearance rate is the volume of water an organism must search to acquire enough food. A clearance rate of $100 \mathrm{~mL}$ ind $^{-1}$ day $^{-1}$, for instance, means that each individual must search $100 \mathrm{~mL}$ of water a day to find enough food. Ingestion rates, on the other hand, are usually expressed as the amount of carbon the organism ingests (Kiørboe 2011).

The distinction between clearance and ingestion rates is important, because they respond differently to environment. For instance, increased food availability tends to increase ingestion rates, up to a maximum value. However, it decreases clearance rates, because organisms must search less to encounter enough resources (Isari and Saiz 2011). Ingestion rates are proportional to body size, but clearance rates are unrelated to it. Instead, clearance rates depend on velocity of prey encounter (Kiørboe 2011). Despite the general rule that temperature, up to a certain point, increases rates of biological processes, ingestion rates decrease with temperature, as a consequence of decreases in body sizes caused by higher temperatures (Saiz and Calbet 2007).

Ecological stoichiometry is another important physiological trait. Ecological stoichiometry, i.e., the proportion of elements that constitute the organisms, is usually defined as C:N:P ratios, and is relatively constant in individuals of the same species (Andersen and Hessen 1991; Wang et al. 2012). Ecological stoichiometry is related to food quality and growth rates (Frost et al. 2005), and creates links between organismal and ecosystem ecology (Elser et al. 2000; Hillebrand et al. 2014). However, the lack of information on elemental composition of species limits its application in functional ecology of communities.

As a general rule, body size is the master trait scaling physiological rates (except for clearance rates). In the oceans of the world, egg production rate of copepods increases with body weight (Bunker and Hirst 2004). In a recent review, it was demonstrated that individual excretion and respiration rates were positively related to dry weight, for different groups of Cladocera and Copepoda, in both freshwater and marine environments (Hébert et al. 2016b). Such information allows us to estimate the impact of zooplankton on nutrient cycles and other ecosystem processes.

\section{Zooplankton effects on ecosystem processes}

In the previous section, we discussed the different types of functional traits and how they respond to environmental changes. In this section, we will discuss how zooplankton traits influence ecosystem functioning. Ecosystem functioning encompasses ecosystem properties, goods, and services. Ecosystem processes include compartments of matter and energy, as well as processes rates. Ecosystem goods and services are related to the human benefit of ecosystem functions (Hooper et al. 2005).

Zooplankton is a trophic link between primary producers (phytoplankton) and higher trophic levels (e.g., fish). It may be constrained by food availability or by predation, i.e., it may be bottom-up or top-down controlled in the trophic web. At the same time, depending on their density, zooplankton may control 
phytoplankton productivity and biomass and prevent blooms (Kasprzak et al. 1999; Gerasimova and Pogozhev 2002). Due to their essential role in trophic webs, they are a significant carbon compartment in freshwater ecosystems, and play an important role in the carbon cycle, as well as to the cycling of nitrogen, phosphorus and other nutrients (Callieri et al. 1999; Alcaraz et al. 2010; Steinberg and Landry 2017).

Zooplankton may have a large impact on trophic structure of whole lakes. In shallow lakes, for example, zooplanktonic grazers may increase benthic productivity by reducing phytoplanktonic productivity (Higgins et al. 2014). In an ecological model with three trophic levels, zooplankton feeding rates and antipredator defense were important functional traits regulating trophic transfer from algae to fish, but it depended on lake trophic status and fish density (Tanaka and Mano 2012). In eutrophic lakes, cyanobacterial dominance may change zooplankton functional trait composition, increasing niche overlap and decreasing functional dispersion (Josué et al. 2019). The absence or low densities of predators decrease the importance of defense-related traits and may increase the importance of traits related to competition among zooplanktonic species (Tanaka 2012). Trait relations among trophic levels are expected to be more complex in food webs with more than three trophic levels (Coll and Hargadon 2012).

The strength of zooplankton-phytoplankton interactions varies considerably among ecosystems, and body size is a key trait to understand it. It is expected that larger zooplankton has a higher impact on primary producers, because feeding rates tend to increase with body size (Kiørboe 2011). For example, at high densities, large-bodied cladocerans may control phytoplankton biomass and primary production in eutrophic lakes (Kasprzak et al. 1999; Gerasimova and Pogozhev 2002). However, these studies were conducted in temperate lakes, where large Daphnia is dominant. In tropical lakes, where small-sized cladocerans are more abundant, top-down control on phytoplankton is weaker (Rejas et al. 2005; Rejas and Muylaert 2010).

However, some research indicates that it is not body size per se that regulates zooplankton control on phytoplankton, but the size structure of both communities. Larger herbivores tend to consume larger phytoplankton cells, and smaller ones tend to consume smaller cells, although there is a lot of variation (Fileto et al. 2004). Thus, when community size structure is diverse, zooplankton feeds on a larger amplitude of phytoplankton cell sizes, strengthening top-down control (Cyr and Curtis 1999; Ye et al. 2013). Indeed, in a microcosm experiment, body size diversity was a strong predictor of top-down control, and phylogenetic diversity was a poor predictor (Gianuca et al. 2016).

Effects of microcrustaceans on carbon and nutrient cycles depend on community biomass, which is linked to functional diversity (Thompson et al. 2015). Thus, indirectly, functional diversity may enhance rates of elemental cycling. More directly, there is evidence that body size magnifies nutrient cycling: larger individuals tend to have higher excretion and respiration rates, thus contributing more to nutrient and carbon cycles (Hébert et al. 2016b). Larger current-feeding herbivores may seem especially important for matter and energy fluxes in the oceans (Benedetti et al. 2018). Marine copepods play an important role in the transport of carbon and other elements by vertical migration and fecal pellet production (Tamelander et al. 2012; Jónasdóttir et al. 2015). Copepod community structure drives fecal pellet production, enhancing carbon flux in these environments (Stamieszkin et al. 2015).

Overall, microcrustacean effect traits are still poorly known. More studies are necessary to point out which traits, other than body size, drive ecosystem processes. Effect traits may be used in modelling to infer about changes in community structure and ecological interactions after environmental change (Tanaka 2012). The current challenge is to link response and effect traits to understand how environmental change may influence ecosystem processes performed by zooplankton. This could increase the predictability of ecological models.

\section{Gaps and constraints of zooplankton functional trait research}

As we defined, functional traits are characteristics of organisms that impact their fitness. We classified them as morphological, life history, behavioral, or physiological. Potentially, a lot of species information could be used as functional traits if linked to relevant ecological processes (Violle et al. 2007). However, information on a trait should be available to all species to be useful at the community level, and the lack of information is still a constraint in functional diversity research. Barnett et al. (2007) compiled literature information on microcrustacean traits, and pointed out a lot of missing data on traits such as food size range, stoichiometric ratios and food selectivity. More recent compilations still point out gaps on functional traits (Hébert et al. 
2016a; Gomes et al. 2019). Here, we summarized information available on response and effect traits for cladocerans and copepods.

The use of functional groups, such as the ones recently proposed for cladocerans (Rizo et al. 2017) and copepods (Benedetti et al. 2016), help overcome the problem by grouping together functionally similar species. The functional groups, then, may be used to answer ecological questions without detailed information on every species.

Recent functional studies, including the functional groups, use mostly qualitative traits, such as feeding type, trophic group, and habitat. Body size is usually the only quantitative trait included (Gomes et al. 2019). That is way, it is easier to find trait values for all species, because these qualitative traits are phylogenetically conservative, i.e., they are the same for all species in a genus or family. A possible problem with this approach is that functional diversity calculated this way could perform poorly or be redundant with taxonomic groups and phylogenetic diversity (Cadotte et al. 2008). However, there is plenty of evidence that it is not always the case (Kelly et al. 2014; Cadotte et al. 2017; Mazel et al. 2017, 2018).

Functional traits should be clearly linked to ecological processes of interest (Petchey and Gaston 2006; Rosado et al. 2013). For zooplankton, the links of functional traits with environmental drivers and ecosystem processes are not always clear. Our review highlights the importance of body size, both as a response and as an effect trait. Other traits need more attention. For example, are the different kinds of filtration for cladocerans [Bosminidae and Daphnidae types, among others (Barnett et al. 2007)] equally efficient, or not, in different conditions? Does the top-down control on phytoplankton depend on filtration type, or is it just a matter of feeding rates and food particle size? Are behavioral escape responses and morphological responses to predator equally efficient at population and community levels? What are the traits that drive competition among zooplankters? In which situations we can or cannot use body size as a proxy for physiological rates?

In freshwaters, there is more information available on cladocerans than copepods. Short life cycles and parthenogenetic reproduction make cladocerans convenient models for laboratory experiments (Suhett et al. 2015). Copepods, on the other hand, have complex life cycles and obligatory sexual reproduction; thus, laboratory populations are harder to maintain. Despite that, they are good model organisms for ecotoxicological studies, and more research on copepods (both freshwater and marine) is needed (Raisuddin et al. 2007; Kulkarni et al. 2013).

However, cladocerans also need further research. Laboratory studies are usually made with Daphnia, with a lack of information on other genera and families. Daphnia species are usually predominant in temperate lakes, but are not so common in tropical ones (Koř́nek 2002; Sarma et al. 2005; Forró et al. 2008). Tropical species may display different responses in life-history traits in response to predators (Santangelo et al. 2018) and temperature, among others (Sarma et al. 2005). The functioning of tropical ecosystems is different from temperate ones (Coll and Hargadon 2012; Catalan and Donato Rondón 2016). In the oceans, tropical calanoids display more complex life-history strategies when compared to temperate ones (Teuber et al. 2019). Thus, the similarities and differences in temperate versus tropical species, in both freshwater and marine ecosystems, is a promising area of research.

Another promising future research is how different traits interact at the individual level. We discussed trade-offs in life-history traits, but there may be trade-offs and synergies among traits that are apparently unrelated. Community assembly and ecosystem processes depend on several processes across trophic levels (de Bello et al. 2010; Mouillot et al. 2011; Spasojevic and Suding 2012). For instance, body size of calanoids is more influenced by temperature than those of cyclopoids, which is related to their feeding type (Horne et al. 2016). A challenge, thus, is to integrate multiple traits across multiple scales to predict ecosystem functions and assembly of multiple communities (Byrnes et al. 2014; Carmona et al. 2016).

One must be aware that the distribution of planktonic taxa may be unpredictable; stochasticity is predominant especially with small-sized organisms (Farjalla et al. 2012; Soininen et al. 2013). Despite that, a trait based approach may provide an underlying explanation for community assembly processes in action (Vogt et al. 2013; Padial et al. 2014). Traits related to dispersal ability and production of dormant stages (Lopes et al. 2016) may be useful. 


\section{Conclusions and perspectives}

Functional traits of zooplanktonic microcrustaceans may be broadly classified as morphological, life history, behavioral, or physiological. Body size, expressed as body length or individual biomass, is the most important trait, because it responds predictably to several environmental conditions, is strongly correlated with ecosystem functions performed by zooplankton, and is a proxy for quantitative physiological rates. Temperature, resource, and predators are among the most important drivers of zooplankton community structure and trait composition. Thus, measuring functional traits in a community may serve as an indicator of environmental characteristics. Integrating environmental and trait data may further be used to infer about ecosystem functions, such as energy transfer in food web and nutrient cycling.

We identified several gaps and opportunities in zooplankton functional trait research. More research is needed to make trait information available on the literature, especially for copepods and neglected tropical species, in both freshwater and marine environments. A further step for future studies is to integrate multiple traits with multiple environmental drivers and ecosystem functions.

Acknowledgements We acknowledge a Doctorate scholarship granted by Coordenação de Aperfeiçoamento de Pessoal de Nível Superior (CAPES) to Elder Sodré. We would like to thank the colleagues who reviewed an early version of the manuscript, greatly improving the quality of the text.

Open Access This article is distributed under the terms of the Creative Commons Attribution 4.0 International License (http:// creativecommons.org/licenses/by/4.0/), which permits unrestricted use, distribution, and reproduction in any medium, provided you give appropriate credit to the original author(s) and the source, provide a link to the Creative Commons license, and indicate if changes were made.

\section{References}

Acerenza L (2016) Constraints, trade-offs and the currency of fitness. J Mol Evol 82:117-127. https://doi.org/10.1007/s00239016-9730-3

Adamczuk M (2010) Different life-history trade-offs of two Daphnia species (Cladocera, Crustacea) under natural conditions as the response to predation and competition. Ann Limnol Int J Limnol 46:241-247. https://doi.org/10.1051/limn/2010022

Adamczuk M (2012) The development and reproductive output of three species of cladocera (crustacea, branchiopoda) with different size spectra as the result of vertebrate and invertebrate predation impact. Invertebr Reprod Dev 56:293-298. https:// doi.org/10.1080/07924259.2011.614281

Alcaraz M, Almeda M, Calbet A et al (2010) The role of arctic zooplankton in biogeochemical cycles: respiration and excretion of ammonia and phosphate during summer. Polar Biol 33:1719-1731. https://doi.org/10.1007/s00300-010-0789-9

Andersen T, Hessen DO (1991) Carbon, nitrogen, and phosphorus content of freshwater zooplankton. Limnol Oceanogr $36: 807-814$

Angilletta MJ, Steury TD, Sears MW (2004) Temperature, growth rate, and body size in ectotherms: fitting pieces of a life-history puzzle. Integr Comp Biol 44:498-509. https://doi.org/10.1093/icb/44.6.498

Atkinson D (1994) Temperature and organism size—a biological law for ectotherms? Adv Ecol Res 25:1-58. https://doi.org/10. 1016/S0306-4565(99)00015-7

Azuraidi OM, Yusoff FM, Shamsudin MN et al (2013) Effect of food density on male appearance and ephippia production in a tropical cladoceran, Moina micrura Kurz, 1874. Aquaculture 412-413:131-135. https://doi.org/10.1016/j.aquaculture.2013. 06.034

Ban S (1994) Effect of temperature and food concentration on post-embryonic development, egg production and adult body size of calanoid copepod Eurytemora affinis. J Plankton Res 16:721-735. https://doi.org/10.1093/plankt/16.6.721

Ban S, Tenma H, Mori T, Nishimura K (2009) Effects of physical interference on life history shifts in Daphnia pulex. J Exp Biol 212:3174-3183. https://doi.org/10.1242/jeb.031518

Barnett AJ, Finlay K, Beisner BE (2007) Functional diversity of crustacean zooplankton communities: towards a trait-based classification. Freshw Biol 52:796-813. https://doi.org/10.1111/j.1365-2427.2007.01733.x

Basińska AM, Antczak M, Świdnicki K et al (2014) Habitat type as strongest predictor of the body size distribution of Chydorus sphaericus (O. F. Müller) in small water bodies. Int Rev Hydrobiol 99:382-392. https://doi.org/10.1002/iroh.201301678

Beaver JR, Tausz CE, Renicker TR et al (2014) The late summer crustacean zooplankton in western USA reservoirs reflects ecoregion, temperature and latitude. Freshw Biol 59:1173-1186. https://doi.org/10.1111/fwb.12338

Benedetti F, Gasparini S, Ayata S-D (2016) Identifying copepod functional groups from species functional traits. J Plankton Res 38:159-166. https://doi.org/10.1093/plankt/fbv096

Benedetti F, Vogt M, Righetti D (2018) Do functional groups of planktonic copepods differ in their ecological niches? J Biogeogr 45:604-616. https://doi.org/10.1111/jbi.13166

Bottrell HH, Duncan A, Gliwicz ZM et al (1976) Review of some problems in zooplankton production studies. Nor J Zool 24:419-456 (citeulike-article-id:4024185) 
Bozkurt A, Can MF (2014) Seasonal variations in body length and fecundity of 2 copepod species: Termocyclops crassus (Fischer, 1853) and Eudiaptomus drieschi (Poppe \& mrázek, 1895). Turk J Zool 38:222-228. https://doi.org/10.3906/zoo-1007-7

Bradley CJ, Strickler JR, Buskey EJ, Lenz PH (2013) Swimming and escape behavior in two species of calanoid copepods from nauplius to adult. J Plankton Res 35:49-65. https://doi.org/10.1093/plankt/fbs088

Brooks JL, Dodson SI (1965) Predation, body size and composition of zoopkankton. Science 150:28-35. https://doi.org/10.1126/ science.150.3692.28

Bruijing M, ten Berge ACM, Jongejans E (2018) Population level responses to temperature, density and clonal differences in Daphnia magna as revealed by integral projection modelling. Funct Ecol Ecol. https://doi.org/10.1111/1365-2435.13192

Brun P, Payne MR, Kiørboe T (2016) Trait biogeography of marine copepods-an analysis across scales. Ecol Lett 19:1403-1413. https://doi.org/10.1111/ele.12688

Bukovinszky T, Verschoor AM, Helmsing NR et al (2012) The good, the bad and the plenty : interactive effects of food quality and quantity on the growth of different Daphnia species. PLoS One. https://doi.org/10.1371/journal.pone.0042966

Bunker AJ, Hirst AG (2004) Fecundity of marine planktonic copepods: global rates and patterns in relation to chlorophyll a, temperature and body weight. Mar Ecol Prog Ser 279:161-181

Bunner HC, Halcrow K (1977) experimental induction of the production of Ephippia by Daphnia magna Straus (Cladocera). Crustaceana 32:77-86

Burks RL, Jeppesen E, Lodge DM (2001) Littoral zone structures as Daphnia refugia against fish predators. Limnol Oceanogr 46:230-237

Burks RL, Lodge DM, Jeppesen E, Lauridsen TL (2002) Diel horizontal migration of zooplankton: costs and benefits of inhabiting the littoral. Freshw Biol 47:343-365

Byrnes JEK, Gamfeldt L, Isbell F et al (2014) Investigating the relationship between biodiversity and ecosystem multifunctionality: challenges and solutions. Methods Ecol Evol 5:111-124. https://doi.org/10.1111/2041-210X.12143

Cadotte MW, Cardinale BJ, Oakley TH (2008) Evolutionary history and the effect of biodiversity on plant productivity. Proc Natl Acad Sci 105:17012-17017. https://doi.org/10.1073/pnas.0805962105

Cadotte MW, Carscadden K, Mirotchnick N (2011) Beyond species: functional diversity and the maintenance of ecological processes and services. J Appl Ecol 48:1079-1087. https://doi.org/10.1111/j.1365-2664.2011.02048.x

Cadotte MW, Davies TJ, Peres-Neto PR (2017) Why phylogenies do not always predict ecological differences. Ecol Monogr 87:535-551. https://doi.org/10.1002/ecm.1267

Calaça AM, Grelle CEV (2016) Diversidade funcional de comunidades: discussões conceituais e importantes avanços metodológicos. Oecol Aust 20:401-416. https://doi.org/10.4257/oeco.2016.2004.01

Callieri C, Pugnetti A, Manca M (1999) Carbon partitioning in the food web of a high mountain lake: from bacteria to zooplankton. J Limnol 58:144-151

Cardinale BJ, Duffy JE, Gonzalez A et al (2012) Biodiversity loss and its impact on humanity. Nature 486:59-67. https://doi.org/ 10.1038/nature11148

Carmona CP, de Bello F, Mason NWH, Lepš J (2016) Traits without borders: integrating functional diversity across scales. Trends Ecol Evol 31:382-394. https://doi.org/10.1016/j.tree.2016.02.003

Catalan J, Donato Rondón JC (2016) Perspectives for an integrated understanding of tropical and temperate high-mountain lakes. J Limnol 75:215-234. https://doi.org/10.4081/jlimnol.2016.1372

Cattaneo A, Asioli A, Comoli P, Manca M (1998) Organisms' response in a chronically polluted lake supports hypothesized link between stress and size. Limnol Oceanogr 43:1938-1943

Černý M, Bytel J (1991) Density and size distribution of Daphnia populations at different fish predation levels. Hydrobiologia 225:199-208

Chang K-H, Hanazato T (2003) Vulnerability of cladoceran species to predation by the copepod Mesocyclops leuckarti: laboratory observations on the behavioural interactions between predator and prey. Freshw Biol 48:476-484

Chapin F III, Zavaleta E, Eviner V et al (2000) Consequences of changing biodiversity. Nature 405:234-242

Choi JY, Kim SK, Chang KH et al (2014) Population growth of the cladoceran, Daphnia magna: a quantitative analysis of the effects of different algal food. PLoS One 9:1-8. https://doi.org/10.1371/journal.pone.0095591

Christofersen K, Riemann B, Klysner A, Sondergaard M (1993) Potential role of fish predation and natural populations zooplankton in structuring a plankton community in eutrophic lake water. Limnol Oceanogr 38:561-573

Cleuvers M, Goser B, Ratte H (1997) Life-strategy shift by intraspecific interaction in Daphnia magna: change in reproduction from quantity to quality. Oecologia 110:337-345

Coll M, Hargadon K (2012) Trophic and functional cascades in tropical versus temperate aquatic microcosms. Aquat Ecol 46:55-71. https://doi.org/10.1007/s10452-011-9381-9

Cruz-cisneros JL, Garc1 L, Mart1 F (2008) A comparison of the response of Simocephalus mixtus (Cladocera) and Daphnia magna to contaminated freshwater sediments. Ecotoxocol Environ Saf 71:26-31. https://doi.org/10.1016/j.ecoenv.2008.05.005

Cyr H, Curtis JM (1999) Zooplankton community size structure and taxonomic composition affects size-selective grazing in natural communities. Oecologia 118:306-315

Daufresne M, Lengfellner K, Sommer U (2009) Global warming benefits the small in aquatic ecosystems. Proc Natl Acad Sci USA 106:12788-12793. https://doi.org/10.1073/pnas.0902080106

de Bello F, Lavorel S, Díaz S et al (2010) Towards an assessment of multiple ecosystem processes and services via functional traits. Biodivers Conserv 19:2873-2893. https://doi.org/10.1007/s10531-010-9850-9

Sodré EO, Figueiredo-Barros MP, Roland F et al (2017) Complimentary biodiversity measures applied to zooplankton in a recovering floodplain lake. Fundam Appl Limnol Arch für Hydrobiol 190:279-298. https://doi.org/10.1127/fal/2017/1064

DeMott WR, Gulati RD, Van Donk E (2001) Daphnia food limitation in three hypereutrophic Dutch lakes: evidence for exclusion of large-bodied species by interfering filaments of cyanobacteria. Limnol Oceanogr 46:2054-2060. https://doi.org/10.4319/ 1..2001.46.8.2054 
Díaz S, Cabido M (2001) Vive la différence: plant functional diversity matters to ecosystem processes. Trends Ecol Evol 16:646-655

Dini ML, Carpenter SR (1992) Fish predators, food availability and diel vertical migration in Daphnia. J Plankton Res 14:359-377

Dumont HJ, Van De Velde I, Dumont S (1975) The dry weight estimate of biomass in a selection of Cladocera, Copepoda and Rotifera from the plankton, periphyton and benthos of continental waters. Oecologia 19:75-97

Dvoretskii VG, Dvoretskii AG (2009) Variability of morphological characteristics in Oithona similis (Copepoda: Cyclopoida) in the White Sea. Russ J Mar Biol 35:259-262. https://doi.org/10.1134/S1063074009030110

Elser JJ, Sterner RW, Gorokhova E et al (2000) Biological stoichiometry from genes to ecosystems. Ecol Lett 3:540-550

Engert A, Chakrabarti S, Saul N et al (2013) Interaction of temperature and an environmental stressor: Moina macrocopa responds with increased body size, increased lifespan, and increased offspring numbers slightly above its temperature optimum. Chemosphere 90:2136-2141. https://doi.org/10.1016/j.chemosphere.2012.10.099

Farjalla VF, Srivastava DS, Marino NAC et al (2012) Ecological determinism increases with organism size. Ecology 93:1752-1759

Feniova IY, Razlutsky VI, Palash AL (2011) Temperature effects of interspecies competition between cladoceran species in experimental conditions. Inl Water Biol 4:65-71. https://doi.org/10.1134/S1995082910041017

Ferrão-Filho AS, Arcifa MS, Fileto C (2003) Resource limitation and food quality for cladocerans in a tropical Brazilian lake. Hydrobiologia 491:201-210. https://doi.org/10.1023/A:1024496611829

Fileto C, Arcifa MS, Ferrão-Filho AS, Silva LHS (2004) Influence of phytoplankton fractions on growth and reproduction of tropical cladocerans. Aquat Ecol 38:503-514. https://doi.org/10.1007/s10452-004-4087-x

Forró L, Korovchinsky NM, Kotov AA, Petrusek A (2008) Global diversity of cladocerans (Cladocera; Crustacea) in freshwater. Hydrobiologia 595:177-184. https://doi.org/10.1007/s10750-007-9013-5

Frost PC, Evans-white MA, Finkel ZV et al (2005) Are you what you eat? Physiological constraints on organismal stoichiometry in an elementally imbalanced world. Oikos 109:18-28

Galiana N, Lurgi M, Montoya JM, López BC (2014) Invasions cause biodiversity loss and community simplification in vertebrate food webs. Oikos 123:721-728. https://doi.org/10.1111/j.1600-0706.2013.00859.x

Gama-Flores JL, Huidobro-Salas ME, Sarma SSS, Nandini S (2011) Somatic and population growth responses of Ceriodaphnia dubia and Daphnia pulex (Cladocera) to changes in food (Chlorella vulgaris) level and temperature. J Environ Biol 32:489-495

Garzke J, Ismar SMH, Sommer U (2015) Climate change affects low trophic level marine consumers: warming decreases copepod size and abundance. Oecologia 177:849-860. https://doi.org/10.1007/s00442-014-3130-4

Gauthier J, Prairie YT, Beisner BE (2014) Thermocline deepening and mixing alter zooplankton phenology, biomass and body size in a whole-lake experiment. Freshw Biol 59:998-1011. https://doi.org/10.1111/fwb.12322

Gerasimova TN, Pogozhev PI (2002) Reduction of the trophic status of a water body with the use of large-size zooplankton. Water Resour 29:412-421

Ghadouani A, Pinel-Alloul B, Prepas EE (2006) Could increased cyanobacterial biomass following forest harvesting cause a reduction in zooplankton body size structure? Can J Fish Aquat Sci 63:2308-2317. https://doi.org/10.1139/f06-117

Gianuca AT, Pantel JH, De Meester L (2016) Disentangling the effect of body size and phylogenetic distances on zooplankton top-down control of algae. Proc Biol Sci. https://doi.org/10.1098/rspb.2016.0487

Giebelhausen B, Lampert W (2001) Temperature reaction norms of Daphnia magna: the effect of food concentration. Freshw Biol 46:281-289

Gillooly JF, Dodson S (2000) Latitudinal patterns in the size distribution and seasonal dynamics of new world, freshwater cladocerans. Limnol Oceanogr 45:22-30. https://doi.org/10.4319/lo.2000.45.1.0022

Gliwicz ZM, Boavida MJ (1996) Clutch size and body-size at first reproduction in Daphnia pulicaria at different levels of food and predation. J Plankton Res 18:863-880

Gliwicz ZM, Umana G (1994) Cladoceran body size and vulnerability to copepod preation. Limnol Oceanogr 39:419-424

Gliwicz ZM, Szymanska E, Wrzosek D (2010) Body size distribution in Daphnia populations as an effect of prey selectivity by planktivorous fish. Hydrobiologia 643:5-19. https://doi.org/10.1007/s10750-010-0125-y

Gomes LF, Pereira HR, Gomes ACAM et al (2019) Zooplankton functional-approach studies in continental aquatic environments: a systematic review. Aquat Ecol. https://doi.org/10.1007/s10452-019-09682-8

Green J (1967) The distribution and variation of Daphnia lumholtzi (Crustacea: Cladocera) in relation to fish predation in Lake Albert, East Africa. J Zool 151:181-197

Greene CH (1983) Selective predation in freshwater zooplankton communities. Int Rev Hydrobiol 68:297-315

Gu L, Lyu K, Dai Z et al (2017) Predator-specific responses of Moina macrocopa to kaironmones from different fishes. Int Rev Hydrobiol 102:83-89. https://doi.org/10.1002/iroh.201601872

Guisande C (1993) Reproductive strategy as population density varies in Daphnia magna (Cladocera). Freshw Biol 29:463-467

Gusha MNC, Dalu T, Wasserman RJ, Mcquaid CD (2019) Zooplankton grazing pressure is insufficient for primary producer control under elevated warming and nutrient levels. Sci Total Environ 651:410-418. https://doi.org/10.1016/j.scitotenv.2018.09.132

Gusso-Choueri PK, Choueri RB, Lombardi AT, Melão MGG (2012) Effects of dietary copper on life-history traits of a tropical freshwater cladoceran. Arch Environ Contam Toxicol 62:589-598. https://doi.org/10.1007/s00244-011-9725-4

Gutiérrez MF, Paggi JC, Gagneten AM (2010) Fish kairomones alter life cycle and growth of a calanoid copepod. J Plankton Res 32:47-55. https://doi.org/10.1093/plankt/fbp095

Hart RC, Bychek EA (2011) Body size in freshwater planktonic crustaceans: an overview of extrinsic determinants and modifying influences of biotic interactions. Hydrobiologia 668:61-108. https://doi.org/10.1007/s10750-010-0400-y

Havens KE, Hanazato T (1993) Zooplankton community responses to chemical stressors: a comparison of results from acidification and pesticide contamination research. Environ Pollut 82:277-288. https://doi.org/10.1016/0269-7491(93)90130G 
Havens KE, Pinto-Coelho RM, Beklioğlu M et al (2015) Temperature effects on body size of freshwater crustacean zooplankton from Greenland to the tropics. Hydrobiologia 743:27-35. https://doi.org/10.1007/s10750-014-2000-8

Hébert M-P, Beisner BE, Maranger R (2016a) A compilation of quantitative functional traits for marine and freshwater crustacean zooplankton. Ecology 97:1081. https://doi.org/10.1890/15-1275

Hébert M-P, Beisner BE, Maranger R (2016b) A meta-analysis of zooplankton functional traits influencing ecosystem function. Ecology 97:1069-1080. https://doi.org/10.1007/s13398-014-0173-7.2

Hébert M-P, Beisner BE, Maranger R (2017) Linking zooplankton communities to ecosystem functioning: toward an effect-trait framework. J Plankton Res 39:3-12. https://doi.org/10.1093/plankt/fbw068

Hellsten ME, Stenson JAE (1995) Cyclomorphosis in a population of Bosmina coregoni. Hydrobiologia 312:1-9. https://doi.org/ 10.1007/BF00018881

Higgins SCN, Althouse B, Devlin SP et al (2014) Potential for large-bodied zooplankton and dreissenids to alter the productivity and autotrophic structure of lakes. Ecology 95:2257-2267

Hillebrand H, Cowles JM, Lewandowska A et al (2014) Think ratio! A stoichiometric view on biodiversity-ecosystem functioning research. Basic Appl Ecol 15:465-474. https://doi.org/10.1016/j.baae.2014.06.003

Hofmann S, Timofeyev MA, Putschew A et al (2012) Leaf litter leachates have the potential to increase lifespan, body size, and offspring numbers in a clone of Moina macrocopa. Chemosphere 86:883-890. https://doi.org/10.1016/j.chemosphere.2011. 10.041

Hooper D, Iii FC, Ewel J et al (2005) Effects of biodiversity on ecosystem functioning: a consensus of current knowledge. Ecol Monogr 75:3-35

Hopcroft RR, Roff JC, Webber MK, Witt JDS (1998) Zooplankton growth rates: the influence of size and resources in tropical marine copepodites. Mar Biol 132:67-77

Horne CR, Hirst AG, Atkinson D et al (2016) A global synthesis of seasonal temperature-size responses in copepods. Glob Ecol Biogeogr 25:988-999. https://doi.org/10.1111/geb.12460

Horne CR, Hirst AG, Atkinson D, Hirst AG (2017) Seasonal body size reductions with warming covary with major body size gradients in arthropod species. Proc R Soc B Biol Sci 284:9. https://doi.org/10.1098/rspb.2017.0238

Huang X, Shi X, Xu S et al (2011) Life history characteristics of Macrothrix rosea (Jurine, 1820) (Cladocera, Macrothricidae) in laboratory conditions. J Limnol 70:248-254. https://doi.org/10.3274/JL11-70-2-13

Huebner JD, Loadman NL, Wiegand MD et al (2013) UVB Radiation affects growth, reproduction and tissue structure of Daphnia magna across several temperatures. Photochem Photobiol 89:103-110. https://doi.org/10.1111/j.1751-1097.2012.01197.x

Hwang JS, Kumar R, Kuo CS (2009) Impacts of predation by the copepod, Mesocyclops pehpeiensis, on life table demographics and population dynamics of four cladoceran species: a comparative laboratory study. Zool Stud 48:738-752

Hylander S, Grenvald JC, Kiørboe T (2014) Fitness costs and benefits of ultraviolet radiation exposure in marine pelagic copepods. Funct Ecol 28:149-158. https://doi.org/10.1111/1365-2435.12159

Isari S, Saiz E (2011) Feeding performance of the copepod Clausocalanus lividus (Frost and Fleminger, 1968). J Plankton Res 33:715-728. https://doi.org/10.1093/plankt/fbq149

Isari S, Antó M, Saiz E (2013) Copepod foraging on the basis of food nutritional quality: can copepods really choose? PLoS One 8:1-12. https://doi.org/10.1371/journal.pone.0084742

Jankowski T (2004) Predation of freshwater jellyfish on Bosmina: the consequences for population dynamics, body size, and morphology. Hydrobiologia 530-531:521-528. https://doi.org/10.1007/s10750-004-2648-6

Jansen M, De Meester L, Cielen A et al (2011) The interplay of past and current stress exposure on the water flea Daphnia. Funct Ecol 25:974-982. https://doi.org/10.1111/j.1365-2435.2011.01869.x

Jeppesen E, Jensen JP, Amsinck S et al (2002) Reconstructing the historical changes in Daphnia mean size and planktivorous fish abundance in lakes from the size of Daphnia ephippia in the sediment. J Paleolimnol 27:133-143. https://doi.org/10.1023/A: 1013561208488

Jónasdóttir SH, Visser AW, Richardson K, Heath MR (2015) Seasonal copepod lipid pump promotes carbon sequestration in the deep North Atlantic. PNAS 112:12122-12126. https://doi.org/10.1073/pnas.1512110112

Josué IIP, Cardoso SJ, Miranda M et al (2019) Cyanobacteria dominance drives zooplankton functional dispersion. Hydrobiologia 831:149-161. https://doi.org/10.1007/s10750-018-3710-0

Kappes H, Sinsch U (2002) Temperature- and predator-induced phenotypic plasticity in Bosmina cornuta and B. pellucida (Crustacea: Cladocera). Freshw Biol 47:1944-1955. https://doi.org/10.1046/j.1365-2427.2002.00943.x

Kasprzak P, Lathrop RC, Carpenter SR (1999) Influence of different sized Daphnia species on chlorophyll concentration and summer phytoplankton community structure in eutrophic Wisconsin lakes. J Plankton Res 21:2161-2174

Kelly S, Grenyer R, Scotland RW (2014) Phylogenetic trees do not reliably predict feature diversity. Divers Distrib 20:600-612. https://doi.org/10.1111/ddi.12188

Kiørboe T (2010) What makes pelagic copepods so successful? J Plankton Res 33:677-685. https://doi.org/10.1093/plankt/fbq159

Kiørboe T (2011) How zooplankton feed: mechanisms, traits and trade-offs. Biol Rev 86:311-339. https://doi.org/10.1111/j.1469185X.2010.00148.X

Klein Breteler WCM, Gonzalez SR (1982) Influence of cultivation and food concentration on body length of calanoid copepods. Mar Biol 71:157-161. https://doi.org/10.1007/BF00394624

Kořínek V (2002) Cladocera. In: Fernando CH (ed) A guide to tropical freshwater zooplankton. Backhuys Publishers, Leiden, p 291

Korosi JB, Paterson AM, Desellas AM, Smol JP (2010) A comparison of pre-industrial and present-day changes in Bosmina and Daphnia size structure from soft-water Ontario lakes. Can J Fish Aquat Sci 67:754-762. https://doi.org/10.1139/F10-013

Korosi JB, Kurek J, Smol JP (2013) A review on utilizing Bosmina size structure archived in lake sediments to infer historic shifts in predation regimes. J Plankton Res 35:444-460. https://doi.org/10.1093/plankt/fbt007 
Koski M, Dutz J, Breteler WK et al (2010) Seasonal changes in food quantity and quality of the common North Sea copepods Temora longicornis and Pseudocalanus elongatus: a bioassay approach. Mar Ecol Prog Ser 399:141-155. https://doi.org/10. 3354/meps08357

Koussoroplis AM, Wacker A (2016) Covariance modulates the effect of joint temperature and food variance on ectotherm lifehistory traits. Ecol Lett 19:143-152. https://doi.org/10.1111/ele.12546

Kozlowski J, Czarnoleski M, Danko M (2004) Can optimal resource allocation models explain why ectotherms grow larger in cold? Integr Comp Biol 44:480-493. https://doi.org/10.1093/icb/44.6.480

Kruk C, Huszar VLM, Peeters ETHM et al (2010) A morphological classification capturing functional variation in phytoplankton. Freshw Biol 55:614-627. https://doi.org/10.1111/j.1365-2427.2009.02298.x

Kulkarni D, Gergs A, Hommen U et al (2013) A plea for the use of copepods in freshwater ecotoxicology. Environ Sci Pollut Res 20:75-85. https://doi.org/10.1007/s11356-012-1117-4

Kumar RAM, Rao TR (1999) Effect of Algal Food on animal prey consumption rates in the omnivorous copepod, mesocyclops thermocyclopoides. Int Rev Hydrobiol 85:419-426

Labaj AL, Kurek J, Smol JP (2014) Chaoborus americanus predation influences Bosmina mucro lengths in fishless lakes. J Paleolimnol 51:449-454. https://doi.org/10.1007/s10933-013-9751-5

Laliberté E, Legendre P (2010) A distance-based framework for measuring functional diversity from multiple traits. Ecology 91:299-305

Lampert W (1989) The adaptive significance of diel vertical migration of zooplankton. Funct Ecol 3:21-27

Lazzaro X (1987) A review of planktivorous fishes: their evolution, feeding behaviours, selectivities, and impacts. Hydrobiologia 146:97-167

Lee HW, Ban S, Ikeda T, Matsuishi T (2003) Effect of temperature on development, growth and reproduction in the marine copepod Pseudocalanus newmani at satiating food condition. J Plankton Res 25:261-271. https://doi.org/10.1093/plankt/25. 3.261

Lepš J, De Bello F, Lavorel S, Berman S (2006) Quantifying and interpreting functional diversity of natural communities: practical considerations matter. Preslia (Prague) 78:481-501

Li C, Yang G, Ning J et al (2013) Response of copepod grazing and reproduction to different taxa of spring bloom phytoplankton in the Southern Yellow Sea. Deep Res Part II 97:101-108. https://doi.org/10.1016/j.dsr2.2013.05.018

Litchman E, Ohman MD, Kiorboe T (2013) Trait-based approaches to zooplankton communities. J Plankton Res 35:473-484. https://doi.org/10.1093/plankt/fbt019

Lopes PM, Bozelli R, Bini LM et al (2016) Contributions of airborne dispersal and dormant propagule recruitment to the assembly of rotifer and crustacean zooplankton communities in temporary ponds. Freshw Biol 61:658-669. https://doi.org/10.1111/ fwb. 12735

Magurran AE (2004) Measuring biological diversity. Blackwell Publishing Ltd, Oxford

Makino W, Ban S (2000) Response of life history traits to food conditions in a cyclopoid copepod from an oligotrophic environment. Limnol Oceanogr 45:396-407. https://doi.org/10.4319/lo.2000.45.2.0396

Manca M, Vijverberg J, Polishchuk LV, Voronov DA (2008) Daphnia body size and population dynamics under predation by invertebrate and fish predators in Lago Maggiore: an approach based on contribution analysis. J Limnol 67:15-21. https://doi. org/10.4081/jlimnol.2008.15

Mason N, Mouillot D, Lee W, Wilson J (2005) Functional richness, functional evenness and functional divergence: the primary components of functional diversity. Oikos 1:112-118

Mazel F, Mooers AO, Riva GVD, Pennell MW (2017) Conserving phylogenetic diversity can be a poor strategy for conserving functional diversity. Syst Biol 66:1019-1027. https://doi.org/10.1093/sysbio/syx054

Mazel F, Pennell MW, Cadotte MW et al (2018) Prioritizing phylogenetic diversity captures functional diversity unreliably. Nat Commun 9:1-9. https://doi.org/10.1038/s41467-018-05126-3

McGill BJ, Enquist BJ, Weiher E, Westoby M (2006) Rebuilding community ecology from functional traits. Trends Ecol Evol 21:178-185. https://doi.org/10.1016/j.tree.2006.02.002

Melle W, Runge J, Head E et al (2014) The North Atlantic Ocean as habitat for Calanus finmarchicus: environmental factors and life history traits. Prog Oceanogr 129:244-284. https://doi.org/10.1016/j.pocean.2014.04.026

Moore M, Folt C (1993) Zooplankton body size and community structure: effects of thermal and toxicant stress. Tree 8:178. https://doi.org/10.1016/0169-5347(93)90144-E

Mouillot D, Villéger S, Scherer-Lorenzen M, Mason NWH (2011) Functional structure of biological communities predicts ecosystem multifunctionality. PLoS One 6:e17476. https://doi.org/10.1371/journal.pone.0017476

Nandini S, Alonso-Soto R, Sarma SSS (2013) Growth of plankton (Scenedesmus acutus (chlorophyceae) and Moina macracopa (cladocera)) on domestic wastewater. Clean Soil Air Water 41:11-15. https://doi.org/10.1002/clen.201000305

Nevalainen L, Rantala MV, Luoto TP (2015) Sedimentary cladoceran assemblages and their functional attributes record late Holocene climate variability in southern Finland. J Paleolimnol 54:239-252. https://doi.org/10.1007/s10933-015-9849-z

Noss RF (1990) Indicators for monitoring biodiversity: a hierarchical approach. Conserv Biol 4:355-364. https://doi.org/10.1111/ j.1523-1739.1990.tb00309.x

O'Brien WJ (2001) Long-term impact of an invertebrate predator, Heterocope septentrionalis, on an arctic pond zooplankton community. Freshw Biol 46:39-45

Padial AA, Ceschin F, Declerck SAJ et al (2014) Dispersal ability determines the role of environmental, spatial and temporal drivers of metacommunity structure. PLoS One 9:1-8. https://doi.org/10.1371/journal.pone.0111227

Padisák J, Crossetti LO, Naselli-Flores L (2009) Use and misuse in the application of the phytoplankton functional classification: a critical review with updates. Hydrobiologia 621:1-19. https://doi.org/10.1007/s10750-008-9645-0

Pajk F, Zhang J, Han BP, Dumont HJ (2018) Thermal reaction norms of a subtropical and a tropical species of Diaphanosoma (cladocera) explain their distribution. Limnol Oceanogr 63:1204-1220. https://doi.org/10.1002/lno.10766 
Pavoine S, Bonsall MB (2011) Measuring biodiversity to explain community assembly: a unified approach. Biol Rev 86:792-812. https://doi.org/10.1111/j.1469-185X.2010.00171.x

Petchey OL, Gaston KJ (2002) Functional diversity (FD), species richness and community composition. Ecol Lett 5:402-411. https://doi.org/10.1046/j.1461-0248.2002.00339.x

Petchey OL, Gaston KJ (2006) Functional diversity: back to basics and looking forward. Ecol Lett 9:741-758. https://doi.org/10. $1111 / \mathrm{j} .1461-0248.2006 .00924 . \mathrm{x}$

Pieters BJ, Liess M (2006) Maternal nutritional state determines the sensitivity of Daphnia magna offspring to short-term Fenvalerate exposure. Aquat Toxicol 76:268-277. https://doi.org/10.1016/j.aquatox.2005.09.013

Pinto-Coelho RM, Bezerra-Neto JF, Miranda F et al (2008) The inverted trophic cascade in tropical plankton communities: impacts of exotic fish in the Middle Rio Doce lake district, Minas Gerais, Brazil. Braz J Biol 68:1025-1037

Pla L, Casanoves F, Di Rienzo J (2012) Functional groups. Quantifying functional biodiversity. Springer, Amsterdam, pp 9-25

Polishchuk LV, Vijverberg J (2005) Contribution analysis of body mass dynamics in Daphnia. Oecologia 144:268-277. https:// doi.org/10.1007/s00442-005-0072-x

Poos MS, Walker SC, Jackson DA (2009) Functional-diversity indices can be driven by methodological choices and species richness. Ecology 90:341-347

Primicerio R (2003) Size-dependent habitat choice in Daphnia galeata Sars and size-structured interactions among zooplankton in a subarctic lake (lake Lombola, Norway). Aquat Ecol 37:107-122. https://doi.org/10.1023/A:1023942931825

Raisuddin S, Kwok KWH, Leung KMY et al (2007) The copepod Tigriopus: a promising marine model organism for ecotoxicology and environmental genomics. Aquat Toxicol 83:161-173. https://doi.org/10.1016/j.aquatox.2007.04.005

Rao TR, Kumar R (2002) Patterns of prey selectivity in the cyclopoid copepod Mesocyclops thermocyclopoides. Aquat Ecol 36:411-424

Rejas D, Muylaert K (2010) Bottom-up and top-down control of phytoplankton growth in an Amazonian várzea lake. Fundam Appl Limnol 176:225-234. https://doi.org/10.1127/1863-9135/2010/0176-0225

Rejas D, Declerck S, Auwerkerken J et al (2005) Plankton dynamics in a tropical floodplain lake: fish, nutrients, and the relative importance of bottom-up and top-down control. Freshw Biol 50:52-69. https://doi.org/10.1111/j.1365-2427.2004.01306.x

Repka S (1997) Effects of food type on the life history of Daphnia clones from lakes differing in trophic state. I. Daphnia galeata feeding on Scenedesmus and Oscillatoria *. Freshw Biol 38:675-683. https://doi.org/10.1046/j.1365-2427.1997.00236.x

Reynolds C, Huszar V, Kruk C et al (2002) Towards a functional classification of the freshwater phytoplankton. J Plankton Res 24:417-428

Rice E, Dam HG, Stewart G (2015) Impact of climate change on estuarine zooplankton: surface water warming in long island sound is associated with changes in copepod size and community structure. Estuaries Coasts 38:13-23. https://doi.org/10. 1007/s12237-014-9770-0

Rizo EZC, Gu Y, Papa RDS et al (2017) Identifying functional groups and ecological roles of tropical and subtropical freshwater Cladocera in Asia. Hydrobiologia 799:1-17. https://doi.org/10.1007/s10750-017-3199-y

Rodgher S, Teresa A, Grac M et al (2009) Evaluation onto life cycle parameters of Ceriodaphnia silvestrii submitted to 36 days dietary copper exposure. Ecotoxicol Environ Saf 72:1748-1753. https://doi.org/10.1016/j.ecoenv.2009.03.009

Rosado B, Dias A, de Mattos E (2013) Going back to basics: importance of ecophysiology when choosing functional traits for studying communities and ecosystems. Nat Conserv 11:15-22

Saiz E, Calbet A (2007) Scaling of feeding in marine calanoid copepods. Limnol Oceanogr 52:668-675. https://doi.org/10.4319/ 10.2007.52.2.0668

Saiz E, Calbet A (2011) Copepod feeding in the ocean: scaling patterns, composition of their diet and the bias of estimates due to microzooplankton grazing during incubations. Hydrobiologia 666:181-196. https://doi.org/10.1007/s10750-010-0421-6

Sakamoto M, Hanazato ÆT, Tanaka Y (2009) Impact of an insecticide on persistence of inherent antipredator morphology of a small Cladoceran, Bosmina. Arch Environ Contam Toxicol 57:68-76. https://doi.org/10.1007/s00244-008-9247-x

San Martin E, Harris RP, Irigoien X (2006) Latitudinal variation in plankton size spectra in the Atlantic Ocean. Deep Res Part II Top Stud Oceanogr 53:1560-1572. https://doi.org/10.1016/j.dsr2.2006.05.006

Santangelo JM, Soares BN, Paes T et al (2018) Effects of vertebrate and invertebrate predators on the life history of Daphnia similis and Moina macrocopa (Crustacea: Cladocera). Ann Limnol Int J Limnol 54:6. https://doi.org/10.1051/limn/2018015

Sarma SSS, Nandini S, Gulati RD (2005) Life history strategies of cladocerans: comparisons of tropical and temperate taxa. Hydrobiologia 542:315-333. https://doi.org/10.1007/s10750-004-3247-2

Sarma SSS, Peredo-Alvarez VM, Nandini S (2007) Comparative study of the sensitivities of neonates and adults of selected cladoceran (Cladocera: Crustacea) species to acute toxicity stress. J Environ Sci Heal Part A Toxic Hazard Subst Environ Eng 43:1449-1452. https://doi.org/10.1080/10934520701480839

Sarma SS, Garcia-Garcia G, Nadini S, Saucedi-Campos AD (2017) Effects of anti-diabetic pharmaceuticals to non-target species in freshwater ecosystems: a review. J Environ Biol 38:1249-1254

Schulte PM, Healy TM, Fangue NA (2011) Thermal performance curves, phenotypic plasticity, and the time scales of temperature exposure. Integr Comp Biol 51:691-702. https://doi.org/10.1093/icb/icr097

Sebastian P, Stibor H, Berger S, Diehl S (2012) Effects of water temperature and mixed layer depth on zooplankton body size. Mar Biol 159:2431-2440. https://doi.org/10.1007/s00227-012-1931-8

Segan DB, Murray KA, Watson JEM (2016) A global assessment of current and future biodiversity vulnerability to habitat lossclimate change interactions. Glob Ecol Conserv 5:12-21. https://doi.org/10.1016/j.gecco.2015.11.002

Sell AF (2000) Morphological defenses induced in situ by the invertebrate predator Chaoborus: comparison of responses between Daphnia pulex and D. rosea. Oecologia 125:150-160

Slusarczyk M (2001) Food threshold for diapause in Daphnia. Ecology 82:1089-1096

Soininen J, Korhonen JJ, Luoto M (2013) Stochastic species distributions are driven by organism size. Ecology 94:660-670 
Spasojevic MJ, Suding KN (2012) Inferring community assembly mechanisms from functional diversity patterns: the importance of multiple assembly processes. J Ecol 100:652-661. https://doi.org/10.1111/j.1365-2745.2011.01945.x

Stamieszkin K, Pershing AJ, Record NR et al (2015) Size as the master trait in modeled copepod fecal pellet carbon flux. Limnol Oceanogr 60:2090-2107. https://doi.org/10.1002/lno.10156

Stearns SC (1976) Life-history tactics: a review of the deas. Q Rev Biol 51:3-47

Steinberg DK, Landry MR (2017) Zooplankton and the ocean carbon cycle. Ann Rev Mar Sci 9:413-444. https://doi.org/10.1146/ annurev-marine-010814-015924

Suchman CL (2000) Escape behavior of Acartia hudsonica copepods during interactions with scyphomedusae. J Plankton Res 22:2307-2323. https://doi.org/10.1093/plankt/22.12.2307

Suhett AL, Steinberg CEW, Santangelo JM et al (2011) Natural dissolved humic substances increase the lifespan and promote transgenerational resistance to salt stress in the cladoceran Moina macrocopa. Environ Sci Pollut Res Int 18:1004-1014. https://doi.org/10.1007/s11356-011-0455-y

Suhett AL, Santangelo JM, Bozelli RL et al (2015) An overview of the contribution of studies with cladocerans to environmental stress research. Acta Limnol Bras 27:145-159

Tamelander T, Aubert AB, Riser CW (2012) Export stoichiometry and contribution of copepod faecal pellets to vertical flux of particulate organic carbon, nitrogen and phosphorus. Mar Ecol Progess Ser 459:17-28. https://doi.org/10.3354/meps09733

Tanaka Y (2012) Trait response in communities to environmental change: effect of interspecific competition and trait covariance structure. Theor Ecol 5:83-98. https://doi.org/10.1007/s12080-010-0100-2

Tanaka Y, Mano H (2012) Functional traits of herbivores and food chain efficiency in a simple aquatic community model. Ecol Model 237-238:88-100. https://doi.org/10.1016/j.ecolmodel.2012.04.021

Teuber L, Hagen W, Bode M, Auel H (2019) Who is who in the tropical Atlantic? Functional traits, ecophysiological adaptations and life strategies in tropical calanoid copepods. Prog Oceanogr 171:128-135. https://doi.org/10.1016/j.pocean.2018.12.006

Thomas CD, Cameron A, Green RE et al (2004) Extinction risk from climate change. Nature 427:145-148. https://doi.org/10. 1038/nature 02121

Thompson PL, Davies TJ, Gonzalez A (2015) Ecosystem functions across trophic levels are linked to functional and phylogenetic diversity. PLoS One 10:e0117595. https://doi.org/10.1371/journal.pone.0117595

Tilman D (1997) The influence of functional diversity and composition on ecosystem processes. Science 277:1300-1302. https:// doi.org/10.1126/science.277.5330.1300

Tollrian R (1995) Predator-induced morphological defenses: costs, life history shifts, and maternal effects in Daphnia Pulex. Ecology 76:1691-1705

Tsuda A, Saito H, Kasai H (2001) Geographical variation of body size of Neocalanus cristatus, N. plumchrus and N. flemingeri in the subarctic pacific and its marginal seas: implications for the origin of the large form of $N$. flemingeri in the Oyashio area. J Oceanogr 57:341-352

Twombly S, Tisch N (2000) Body size regulation in copepod crustaceans. Oecologia 122:318-326. https://doi.org/10.1007/ s004420050037

Vesela S, Vijverberg ÆJ (2007) Effect of body size on toxicity of zinc in neonates of four differently sized Daphnia species. Aquat Ecol 41:67-73. https://doi.org/10.1007/s10452-006-9050-6

Viitasalo M, Koski M, Pellikka K, Johansson S (1995) Seasonal and long-term variations in the body size of planktonic copepods in the northern Baltic Sea. Mar Biol 123:241-250. https://doi.org/10.1007/BF00353615

Violle C, Navas M-L, Vile D et al (2007) Let the concept of trait be functional! Oikos 116:882-892. https://doi.org/10.1111/j. 2007.0030-1299.15559.x

Violle C, Reich PB, Pacala SW et al (2014) The emergence and promise of functional biogeography. Proc Natl Acad Sci 111:13690-13696. https://doi.org/10.1073/pnas.1415442111

Vogt RJ, Peres-Neto PR, Beisner BE (2013) Using functional traits to investigate the determinants of crustacean zooplankton community structure. Oikos 122:1700-1709. https://doi.org/10.1111/j.1600-0706.2013.00039.x

Wang H, Sterner RW, Elser JJ (2012) On the "strict homeostasis" assumption in ecological stoichiometry. Ecol Model 243:81-88. https://doi.org/10.1016/j.ecolmodel.2012.06.003

White MM, Mclaren IA (2000) Copepod development rates in relation to genome size and 18S rDNA copy number. Genome 43:750-755

Yan ND, Somers KM, Girard RE et al (2008) Long-term trends in zooplankton of Dorset, Ontario, lakes: the probable interactive effects of changes in $\mathrm{pH}$, total phosphorus, dissolved organic carbon, and predators. Can J Fish Aquat Sci 65:862-877. https://doi.org/10.1139/f07-197

Yang EJ, Ju S-J, Choi J-K (2010) Feeding activity of the copepod Acartia hongi on phytoplankton and micro-zooplankton in Gyeonggi Bay, Yellow Sea. Estuar Coast Shelf Sci 88:292-301. https://doi.org/10.1016/j.ecss.2010.04.005

Ye L, Chang C, Garc1 C et al (2013) Increasing zooplankton size diversity enhances the strength of top-down control on phytoplankton through diet niche partitioning. J Anim Ecol 82:1052-1060. https://doi.org/10.1111/1365-2656.12067

Yen J, Murphy DW, Fan L, Webster DR (2015) Sensory-motor systems of copepods involved in their escape from suction feeding. Integr Comp Biol 55:121-133. https://doi.org/10.1093/icb/icv051

Zaret TM (1980) Predation and freshwater communities. Yale University Press, New Haven and London

Zaret TM, Kerfoot WC (1975) Fish predation on Bosmina longirostris: body-Size selection versus visibility selection. Ecology 56:232-237

\section{Publisher's Note}

Springer Nature remains neutral with regard to jurisdictional claims in published maps and institutional affiliations. 